http://journal.uinsgd.ac.id/index.php/biodjati

\title{
BIOCONVERSION OF FERMENTED BARLEY WASTE BY BLACK SOLDIER FLY Hermetia illucens L. (DIPTERA; STRATIOMYIDAE)
}

\author{
Agus Dana Permana ${ }^{1 *}$, Din Dzakamala Fafi Rohmatillah ${ }^{2}$, \\ Ramadhani Eka Putra ${ }^{3}$, Ucu Julita ${ }^{4}$, Agus Susanto ${ }^{5}$
}

Received : October 19, 2021

Accepted : November 14, 2021

DOI: 10.15575/hindjativ6i2.14609

${ }^{1}$ School of Life Sciences and Technology, Institut Teknologi Bandung, Jl. Ganesa 10 Bandung, West Java Indonesia, 40132,

${ }^{2}$ Department of Biology, Faculty of Science and Technology UIN Sunan Gunung Djati; Jl. AH. Nasution 105 Bandung, West Java, Indonesia, 40614 ${ }^{3}$ Departemen Hama dan Penyakit Tumbuhan Fakuktas Pertanian Universitas Padjadjaran Jl. Bandung Sumedang KM 21 Jatinangor Sumedang, West Java Indonesia, 45362.

e-mail:

*1agus@sith.itb.ac.id,

2dindza17@gmail.com,

ramadhani@sith.itb.ac.id,

4ucujulita@uinsgd.ac.id,

5asusanto@unpad.ac.id

*Corresponding author

Abstract. Black Soldier Fly Larvae (BSFL), Hermetia illucens (Diptera: Stratiomyidae) are widely used as bioconverter agents for various organics waste, and BSF pupae are often used as fodder for poultry and fish, because the BSF pupae have a high protein content. This study focused on applying BSFL as a bioconversion agent of the fermented barley waste to convert it to larvae biomass. Prior to application, barley waste was fermented either using effective microorganisms-4 (EM4), leachate, and water for seven days. The fermented barley waste was applied as feeding material for BSFL at the rate of $100 \mathrm{mg} /$ larvae/days. As control commercial chicken fed (CF) was applied as feeding material at a similar feeding rate. During this study, waste reduction index (WRI), and efficiency of digested feed (ECD) were calculated, and the protein content in the $B S F$ prepupae was analyzed. The results of this study showed that $B S F L$ fed with CF produces the shortest development time (27 days), and high consumption rate. BSFL fed with barley waste fermented with EM4 (BE) and Leachate (BL) produces a larval period of 31 and 30 days respectively, and statistically those were not significantly different from control. This study showed that treatments of $B E$ and BL, produced a very high larval survival rates, $98.67 \%$ and $97.00 \%$ respectively, and those two treatments were not statistically different from the control (96.67\%). Although the control treatment resulted in a higher WRI compared to the other treatments, but the ECD of BE and $B L$ treatments were higher than the ECD of the control. From this study, it can be concluded that BSFL has a good ability to convert fermented barley waste as well as controls, and the prepupae has a high protein content (42\%), so BSFL fed with fermented barley waste has the opportunity to be used as a fed for poultry and fish.

Keywords: barley, bioconversion, biomass, efficiency, husks

\section{Citation}

Permana, A. D., Rohmatillah, D. D. F., Putra, R. E., Julita, U. \& Susanto, A. (2021). Bioconversion of Fermented Barley Waste by Black Soldier Fly Hermetia illucens L. (Diptera ; Stratiomyidae). Jurnal Biodjati, 6(2), 235-245.

\section{INTRODUCTION}

Various agro-industrial waste is often used for animal feed, including palm kernel mills, cassava from tapioca factories, wine factory waste, tofu dregs, and barley waste. The waste can be directly given to ruminant animals, but some types of agro-industrial waste require a fermentation process before being used as animal feed. Barley waste is the most considerable waste generated from several agroindustries, about $85 \%$ of the total waste produced (Lima, 2010; Mathias et al., 2014). Barley waste consists of $15-26.2 \%$ 


\section{JURNAL BIDDJATI}

http://journal.uinsgd.ac.id/index.php/biodjati

protein and $70 \%$ fiber, which is divided into three fractions: cellulose (15.5-25\%), hemicellulose (especially arabinoxylans, 28$35 \%$ ), lignin (approx. 28\%), lipids (3.9-10\%), ash (2.5-4.5\%), vitamins, amino acids, and phenolic compounds (Mussato et al., 2006; Lima, 2010; Robertson et al., 2010; Aliyu et al., 2011; Mathias et al., 2014). Nowadays, barley waste is managed, on a very limited scale, for animal feed due to its high protein content of the material which produced a positive effect on cattle weight (Chrisdiyanto et al., 2018). Since a significant amount of barley waste is produced daily which is higher than the cattle requirement it is necessary to develop an alternative management strategy for this material. In the last decade, there have been many studies on the biowaste conversion process using Hermetia illucens L. (Diptera: Stratiomyidae), commonly known as black soldier fly (BSF). H. illucens larvae can convert several organic wastes into body biomass rich in protein (more than $30 \%$ crude protein) and lipid (30\% crude fat). In addition, H. illucens are auspicious because a source of protein for animal and fish feed and become an alternative to conventional feed. Several studies (Makkar et al., 2014; Lock et al., 2015; Veldkamp et al., 2015; Gasco et al., 2016; Ji et al., 2016; Renna et al., 2017; Schiavone et al., 2017) showed that BSF larvae (BSFL) are applicable as an alternative substitute for fish meal and soybean meal in poultry, pork, and fish feed in almost all parts of the world and also provide business opportunities (Van Huis et al., 2013; Kelemu et al., 2015; Dobermann et al., 2017).

BSF is also applicable to decomposed agricultural waste containing high lignocellulose although relatively inefficient (Manurung et al., 2016; Supriyatna et al., 2017; Liu et al., 2018; Chia et al., 2018). This condition is due to (1) the lack of a digestive enzyme to necessary digest lignocellulose (Ohkuma, 2003; Amin et al., 2017) and (2) the low nitrogen content of the substrate (Meneguz et al., 2019). There were several strategies to improve the digestibility of the lignocellulose rich substrate by BSFL, such as (1) pre-treatment of the substrate through the application of microbes or chemicals which hydrolyzed the lignocellulose, (2) addition of nitrogen-rich material to the substrate, and (3) combination with lignin-consumer, such as Tenebrio molitor (Wang et al., 2017).

In this study, a pre-treatment process, substrate fermentation was applied to improve the digestibility of the substrate. Unlike other studies which applied specific types of microbes, that may impractical for smallscale and low-budget system application, a much common microbial consortium (named Effective Microorganism 4), leachate, and water (utilized microbes naturally occur on barley waste). Thus, the purpose of this study was to assess the effectiveness of pre-treatment of barley waste for the bioconversion process by BSFL.

\section{MATERIALS AND METHODS}

\section{Study Site}

This research was conducted in the Laboratory of Environmental Toxicology, School of Life Sciences and Technology, Institut Teknologi Bandung (SITH-ITB), for seven months, in September 2020-March 2021.

\section{Black Soldier Fly Larvae}

BSFL obtained from a population were kept in the Laboratory of Environmental Toxicology, School of Life Science and Technology, Institut Teknologi Bandung. The larvae used in this study were 6 days old larvae. All larvae were kept at room temperature (18- 


\section{JURNAL BIDDJATI}

http://journal.uinsgd.ac.id/index.php/biodjati

$30^{\circ} \mathrm{C}$ ), relative humidity $60-90 \%$, and $12: 12$ hour day: night period.

\section{Waste Material}

Barley waste was originated from the soya milk industry in Cimahi, Indonesia. Barley waste consists of barley husks $(\mathrm{BH})$ and barley seeds. Before application as feeding material, barley waste and $\mathrm{BH}$ were fermented by $5 \%$ EM4 (PT. Songgolangit Persada), $0.5 \%$ leachate as a byproduct of tomato waste bioconversion by BSF larvae, and distilled water for 5 days. EM4 and leachate were dissolved in sterile distilled water, then barley waste and $\mathrm{BH}$ were added to fermentation solution, then stored in the laboratory (room temperature). The solution was filtered and stored as an ingredient for increasing the water content of the substrate. The experimental diets for this study were: husks fermented by EM4 (HE), barley spend ground fermented by EM4 (BE), husks fermented by leachate (HL), barley spend ground fermented by leachate (BL), husks fermented by water (HW), barley seeds fermented by water (BW), and chicken fed (CF) was used as a control.

\section{Bioconversion Study}

BSFL aged six days were fed by all treatment with a daily feeding rate of $100 \mathrm{mg} /$ day/larvae. A hundred larvae were used for each treatment in three replications (Diener et al., 2009). Larvae were placed inside a plastic cup $(5 \mathrm{~cm} x$ height $8 \mathrm{~cm})$ and covered by gauze. Every three days, larvae were transferred to another cup with the required feeding material. The residue from the previous cup was weighed and dried in an oven at $60^{\circ} \mathrm{C}$ for 72 hours to determine the dry mass. The study was conducted until at least $60 \%$ of total larvae reached prepupal (Tomberlin et al., 2002; Diener et al., 2009). All prepupal were removed daily from each cup and weighed, then dried in an oven at $60^{\circ} \mathrm{C}$ for 72 hours to determine the dry mass.

\section{Substrate Consumption}

Substrate consumption was feeding consumption during an experiment and it was calculated in its dry base (db) weight (Diener et al., 2009) :

Survival rate $=\frac{\text { numbers of larvae survive }}{\text { numbers of initial larvae }} \times 100 \%$

\section{Survival Rate}

Survival rate was measured to determine total larvae survival during the experiment following the equation below (Myers et al., 2008):

Survival rate $=\frac{\text { numbers of larvae survive }}{\text { numbers of } \text { initial larvae }} \times 100 \%$

\section{Waste Reduction}

Waste reduction index (WRI) is the ability of larvae to reduce feeding substrates during a specific time. Higher values show a greater ability of larvae to reduce substrate or organic matter. The formula follows the equation below (Diener et al., 2009):

$$
\text { WRI }=\frac{\text { total feeding }(d b)-\text { residue }(d b)}{\text { total feeding }(d b)} \div \text { time } \times 100 \%
$$

\section{The efficiency of digested feed}

The efficiency of digested feed (ECD) is based on terminology Scriber \& Slanssky (1981).

$\mathrm{ECD}=\frac{\text { biomass }(d b)}{\text { total feeding }(d b)-\text { total residue }(d b)} \times 100 \%$

Biomass and Chemical Analysis of Larvae

The biomass of larvae was measured from the final weight of larvae, and it was calculated in a dry base (Diener et al., 2009). Chemical analysis of larvae with proximate analysis was performed at Pusat Pelayanan Basic Science (PPBS) of Padjajaran University. 


\section{JURNAL BIDDJATI}

http://journal.uinsgd.ac.id/index.php/biodjati

\section{Data analysis}

Data collection among treatments was statistically analyzed with one-way ANOVA at a significant rate of 0,05 and followed by the Tukey test for post hoc test. All analysis was done with IBM SPSS 25 software.

\section{RESULTS AND DISCUSSION}

\section{Larval Growth}

The development time of larvae fed with chicken feed was lower than other groups ( $27 \pm 0.00$ days), followed by barley waste fermented by leachate $(30 \pm 1.00)$ days and EM4 (31 \pm 0.00 days). The larval period of those 3 treatments was not a statistically significant difference. On other hand, larvae fed on fermented barley required less development time than the group fed on fermented husk (47-52 days) (Table 1).

The highest survival rate $(98.67 \pm 0.67 \%)$ was recorded from the group fed with barley waste fermented by EM4 (BE). Statistically, all treatments resulted in a survival rate that was not significantly different, except for the barley husk fermented with water (HW) (Table 1). Substrate consumption by BSF larvae was varied from $45.07 \%$ in $\mathrm{BE}$ treatment to 52.78 in the BW treatment. The value of substrate consumption between treatments was not significantly different from the results of statistical analysis (ANOVA, $\mathrm{p}=0.001$ ).

The longer development time for BSFL fed on barley waste may be related to the high lignin and fiber of barley endosperm (the main component of barley waste) (Lynch et al., 2016). BSFL do not have lignin-degrading enzymes in their intestines so that the larvae will find it challenging to digest substrates containing lignocellulose (Kim et al., 2011; Zheng et al., 2012). Under malnourished conditions, BSFL can prolong the life cycle (Dortmans et al., 2017). This development time of BSFL fed on barley waste substrate was longer than Liu et al. (2018) (average development time $=14.97$ days $)$ and Chia et al. (2018) (development time $=16-21$ days). Differences between studies may be due to variations in the quantity and quality of feed given to larvae and also this study used the old and dried barley waste while previous studies applied the fresh barley waste. Studies showed that hard material may significantly reduce the ability of BSFL to digest it (Gobbi et al., 2013; Nguyen et al., 2013).

Table 1. Development time, survival rate, and substrate consumption of Hermetia illucens (HE = husk/EM4; BE = barley/EM4; HL = husk/leachate; $\mathrm{BL}=$ barley/leachate; $\mathrm{HW}=$ husk/water; $\mathrm{BW}=$ barley/water; $\mathrm{CF}=$ chicken feed).

\begin{tabular}{|c|c|c|c|c|c|c|c|}
\hline Parameter & HE & BE & $\mathbf{H L}$ & $\mathrm{BL}$ & HW & BW & CF \\
\hline Development time & $52.00 \pm$ & $31.00 \pm$ & $48.00 \pm$ & $30.00 \pm$ & $47.00 \pm$ & $32.00 \pm$ & $27.00 \pm$ \\
\hline (day) & $1.00 \mathrm{a}$ & $0.00 \mathrm{~cd}$ & $2.00 \mathrm{ab}$ & $1.00 \mathrm{~cd}$ & $0.00 \mathrm{~b}$ & $0.88 \mathrm{c}$ & $0.00 \mathrm{~d}$ \\
\hline Survival rate $(\%)$ & $\begin{array}{l}91.33 \pm \\
0.67 \mathrm{ab}\end{array}$ & $\begin{array}{l}98.67 \pm \\
0.67 \mathrm{a}\end{array}$ & $\begin{array}{l}81.67 \pm \\
0.88 \mathrm{ab}\end{array}$ & $\begin{array}{l}97.00 \pm \\
1.73 a\end{array}$ & $\begin{array}{l}68.33 \pm \\
13.20 \mathrm{~b}\end{array}$ & $\begin{array}{l}79.33 \pm \\
3.28 \mathrm{ab}\end{array}$ & $\begin{array}{l}96.67 \pm \\
0.33 \mathrm{a}\end{array}$ \\
\hline $\begin{array}{l}\text { Substrate } \\
\text { consumption (\%) }\end{array}$ & $\begin{array}{l}45.67 \pm \\
0.91 b c\end{array}$ & $\begin{array}{l}45.07 \pm \\
0.58 \mathrm{c}\end{array}$ & $\begin{array}{l}46.93 \pm \\
0.65 \mathrm{bc}\end{array}$ & $\begin{array}{l}50.93 \pm \\
0.81 \mathrm{abc}\end{array}$ & $\begin{array}{l}49.54 \pm \\
1.30 \mathrm{bc}\end{array}$ & $\begin{array}{l}52.78 \pm \\
0.46 \mathrm{ab}\end{array}$ & $\begin{array}{l}57.52 \pm \\
0.16 \mathrm{a}\end{array}$ \\
\hline
\end{tabular}

\section{Larval Biomass and Proximate}

The highest larval biomass was the barley fermented by EM4 (BE) (55.46 mg), and the lowest was husks fermented by EM4 (HE) $(28.62 \mathrm{mg})$. The chicken feed substrate analysis results were not significantly different from the fermented barley substrate but were significantly different from the fermented husk substrate. The difference between husk and barley substrate showed significantly different 


\section{JURNAL BIODJATI}

http://journal.uinsgd.ac.id/index.php/biodjati

results, but differences in pre-treatment (fermentation) did not show significantly different (Figure 1). The pattern proportion of feed converted into prepupal biomass, used for metabolism, and undigested or residue were different in all treatjment. The highest prepupal biomass generated by group $\mathrm{CF}$ and most of feed converted into residu (Figure 2). Proximate analysis was carried out on EM4 fermented barley treatment because it was the best result compared to other treatments. The proximate results obtained were crude protein $(42.86 \%)$, crude fat $(32.43 \%)$, and ash (3.87\%) (Table 2).

$H$. illucens larvae's ability to convert barley waste substrates is due to the digestive enzymes in their intestines, such as amylase, protease, and lipase, which work most effectively in hydrolyzing the substrate. In addition to these enzymes, there are leucine arylamidase, $\alpha$-galactosidase, $\beta$-galactosidase, and $\alpha$-mannosidase, which are not present in Musca domestica flies but work very effectively on $H$. illucens larvae (Kim et al., 2011). In addition to H. illucens larvae's ability to degrade the substrate, this study used fermented substrates to make it easier for larvae to digest the substrate as they had high lignin and fiber content.

The proximate analysis of $H$. illucens fed with barley waste showed a high content of crude protein (42.86) (Table 2). This indicates that BSF larvae are very suitable for use as poultry and fish feed (Schiavone et al., 2017; Renna et al., 2017; Henry et al., 2015). Zheng et al. (2013) stated that H. illucens could increase the protein and fat content in organic waste that could be used for animal feed. Makkar et al. (2014) and Henry et al. (2015) revealed that BSF larvae produce body biomass with high protein and fat content, so it is very suitable to be used as animal feed. Elwert et al. (2010) reported that the weight of chicken cultivated with feed containing 4.7-6.6\% BSF larvae was comparable to the weight of chicken fed with a fish meal (3\%) as a source of animal protein. Moula et al. (2018) reported that the weekly weight of Ardennaise chickens fed on commercial feed substituted by $8 \%$ of BSF larvae was slightly higher than control. Cullere et al. (2016), stated that $H$. illucens larvae meal can replace conventional soya bean meal and soya bean oil in the feed for growing broiler quails, thus confirming it as a promising source of insect protein for the feed industry.

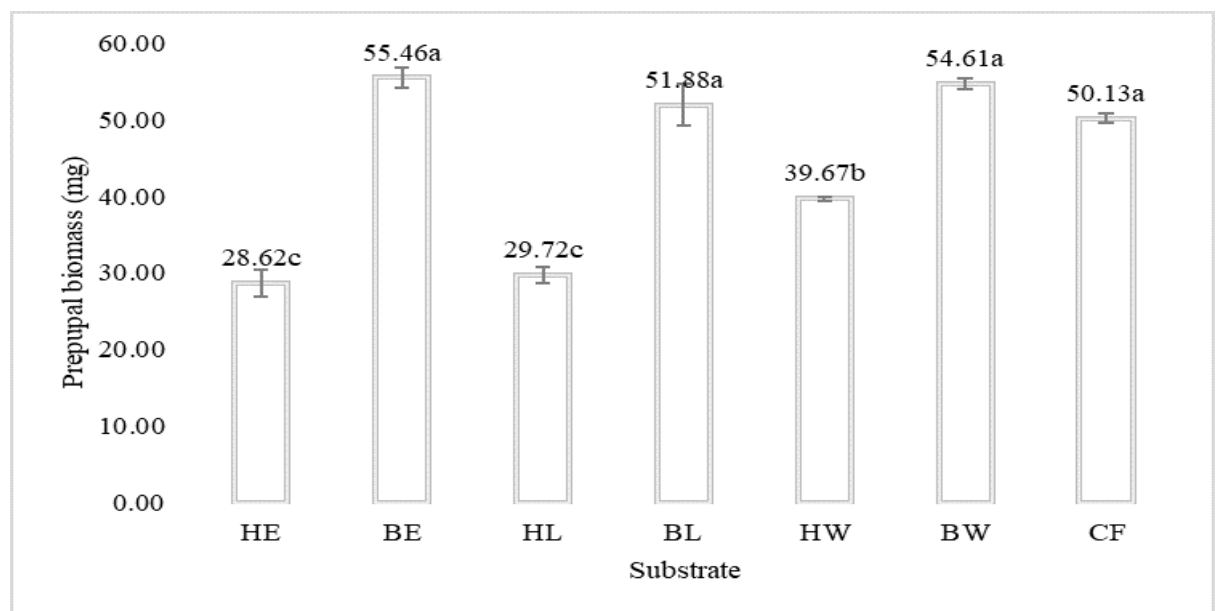

Figure 1. Prepupal weight of black soldier fly larvae fed on barley waste. (husk/EM4, HE; barley/EM4, BE; husk/leachate, HL; barley/leachate, BL; husk/water, 


\section{JURNAL BIDDJATI}

http://journal.uinsgd.ac.id/index.php/biodjati



Figure 2. Proportion of feed converted into prepupal biomass, used for metabolism, and residue by black soldier fly larvae. (husk/EM4, HE; barley/EM4, BE; husk/ leachate, HL; barley/leachate, BL; husk/water, HW; barley/water, BW; chicken

Table 2. Chemical composition of black soldier fly prepupae on barley fermented by EM4 (BE)

\begin{tabular}{ll} 
Chemical composition & Prepupae $(\%)$ \\
\hline Water content & 15.34 \\
Crude protein content & 42.86 \\
Crude fat content & 32.43 \\
ash content & 3.87 \\
\hline
\end{tabular}

\section{Waste Reduction Index (WRI) and Efficiency of Digested Feed (ECD)}

The WRI value was applied to express the amount of substrate ingested by larvae in a certain period. In contrast, the ECD value represents the conversion potency of a substrate or ingested food into larval biomass (Diener et al., 2009). The highest WRI value of this study was $2.74 \pm 0.01$ which was recorded from the group fed with the chicken feed and the lowest WRI value was the group fed with husk fermented by EM4 (0.99 \pm 0.03). The highest ECD value was recorded from the group fed with barley fermented by EM4 $(7.24 \pm 0.05 \%)$ and the group fed with husk fermented by leachate has the lowest $(4.76 \pm 0.15 \%)$ (Table 3$)$.

Table 3. Waste reduction index (WRI) and Efficiency of Conversion of Digested Food (ECD) of black soldier fly larvae fed barley waste. (HE = husk/EM4; BE = barley/EM4; HL = husk/leachate; $\mathrm{BL}=$ barley/leachate; $\mathrm{HW}=$ husk/water; $\mathrm{BW}=$ barley/water; $\mathrm{CF}=$ chicken feed).

\begin{tabular}{lccccccc}
\hline Parameter & HE & BE & HL & BL & HW & BW & CF \\
\hline \multirow{2}{*}{ WRI } & $0.09 \pm$ & $1.80 \pm$ & $1.12 \pm$ & $2.13 \pm$ & $1.21 \pm$ & $2.04 \pm$ & $2.74 \pm$ \\
& $0.03 \mathrm{c}$ & $0.02 \mathrm{~b}$ & $0.06 \mathrm{c}$ & $0.13 \mathrm{~b}$ & $0.03 \mathrm{c}$ & $0.08 \mathrm{~b}$ & $0.01 \mathrm{a}$ \\
ECD (\%) & $5.02 \pm$ & $7.24 \pm$ & $4.76 \pm$ & $7.08 \pm$ & $5.61 \pm$ & $6.30 \pm$ & $6.66 \pm$ \\
& $0.31 \mathrm{~b}$ & $0.05 \mathrm{a}$ & $0.15 \mathrm{~b}$ & $0.33 \mathrm{a}$ & $0.35 \mathrm{ab}$ & $0.27 \mathrm{ab}$ & $0.09 \mathrm{ab}$ \\
\hline
\end{tabular}




\section{JURNAL BIDDJATI}

http://journal.uinsgd.ac.id/index.php/biodjati

The high fiber content (70\%) in barley waste needs to be fermented to break down cellulose and lignin. EM4 as a product of effective microorganisms contains cellulosedegrading fungi, Lactobacillus, phosphorous solubilizing bacteria, Streptomyces, and lactic acid bacteria seem to be effective in breaking down the fiber in barley waste. Leachate from the bioconversion of tomato waste by BSF larvae also contains various microorganisms that may be able to break down the fiber in barley waste, although in more detail the types of microorganisms in leachate still need to be investigated. Barley husk is part of the barley seed called lemma and palea and is the hardened seed coat (Brenan et al., 2019). Barley husk-like rice husk which is processed into flour is often used as additional feed for chickens and ducks. The nutritional content of barley husk is much lower than barley waste and has a high starch content (Gujral et al., 2018; Grant et al., 2020). This may have an effect that causes BSF larvae to have difficulty digesting barley husk even though it has been fermented with EM4 or leachate.
This study observed the benefit of a pre-treatment process for bioconversion of barley waste into the biomass of H. illucens. The pre-treatment process applied in this study produced the substrate consumption rate ranging from $45.07-57.52 \%$, indicating an incomplete fermentation process of the substrate so that $H$. illucens larvae still have difficulty digesting the substrate. However, the biomass obtained was high compared to several other studies with a similar feeding rate and substrate properties (high lignin and cellulose) (Table 4). Some organic waste such as coconut dregs which contain high lignocellulose has also been successfully used as feed for H. illucens larvae and as oviposition site of adult females of black soldier fly (Hasan \& Dina, 2019). It seems that the high protein content of the substrate compensates for the lack of digestibility on the substrate which is indicated by the high crude protein content of the prepupae. However, interestingly the protein content in larvae is not directly related to the feed consumed (Simpson \& Simpson, 1990).

Table 4. Comparative data on larval biomass of black soldier fly on various substrates

\begin{tabular}{lll}
\hline \multicolumn{1}{c}{ Reference } & \multicolumn{1}{c}{ Substrate } & \multicolumn{1}{c}{ Biomass (mg) } \\
\hline Manurung et al. (2016) & Rice straw & 13.64 \\
Supriyatna et al.(2017) & Fermented rice straw & 13.68 \\
Liu et al. (2018) & Brewer's waste & 34.54 \\
Liu et al. (2018) & Pig manure & 13.98 \\
This study & Barley waste & $28.62-55.46$ \\
\hline
\end{tabular}

The protein content and amino acid profile of prepupae are not dependent on protein content and quality of the substrates they are feed (Spranghers et al., 2017; Barragan-Fonseca et al., 2018). For example, Liu et al., (2018) reported that prepupae fed with standard diet and barley waste had similar protein content, whereas the protein content of the standard diet was only $70 \%$ than barley waste. A possible explanation for this is larvae fed with a standard diet could further increase protein assimilation to maintain protein homeostasis than larvae fed with barley waste, and Simpson \& Simpson (1990) stated 


\section{JURNAL BIDDJATI}

http://journal.uinsgd.ac.id/index.php/biodjati

this phenomenon as a compensatory response to nutritional deficiencies or imbalances often found in phytophage insect species. However, Nguyen et al., (2015) reported that H. illucens fed with high protein content such as liver or meat produced a higher protein content in the pupae $(60 \%)$, and this protein content was higher than that of $H$. illucens which fed the vegetable waste $(38 \%)$.

From the results of this study, it can be concluded that the larvae of Hermetia illucens L. have the potential to convert fermented barley waste into their body biomass, and the resulting prepupae contains high protein, which can be used as poultry feed. However, there is a need for further study to compare the fermentation treatment of barley waste using bacteria or fungi that have a specific ability to degrade lignin to ascertain that the substrate is entirely degraded and more comfortable to digest by $H$. illucens larvae.

\section{ACKNOWLEDGEMENT}

This study was funded by ITB Research Grant, Contract No: 1109/11.C02.2/KU/2020 for Agrotechnology \& Bioproduct Research Group.

\section{REFERENCES}

Aliyu, S. \& Bala, M. (2011). Brewer's spent grain: A review of its potentials and applications. African Journal of Biotechnology, 103(3), 324-331.

Amin, F. R., Khalid, H., Zhang, H., Rahman, S. U., Zhang, R., Liu, G. \& Chen, C. (2017). Pretreatment Methods of Lignocellilosic Biomass for Anaerobic Digestion. AMB Express, 7, 72.

Barragán-Fonseca, K. B. (2018). Flies Are What They Eat: Tailoring Nutrition of Black Soldier Fly (Hermetia illucens
L.) for Larval Biomass Production and Fitness. PhD thesis. Wageningen University, Wageningen.

Brennan, M., Hedley, P. E., Topp, C. F. E., Morris, J., Ramsay, L., Mitchell, S., Shepherd, T., Thomas, W. T. B. \& Hoad, S. P. (2019). Developmentand Quality of Barley Husk AdhesionCorrelates With Changes in Caryopsis Cuticle Biosynthesisand Composition. Frontriers in Plant Science, 10, 672.

Chrisdiyanto, E., Erlista, G.P. \& Rosyida, E. I. (2018). Pengaruh Pemberian Pakan Fermentasi Limbah Ampas Bir Terhadap Peningkatan Pertumbuhan Daging Sapi Potong. Prosiding Seminar Nasional Jurusan Pendidikan Biologi. ISBN 978-602-97298-3.

Chia, S. Y., Tanga, C. M., Osuga, I. M., Mohamed, S. A., Khamis, F. M., Salifu, D., Sevgan, S., Fiaboe, K. K. M., Niassy, S., van Loon, J .J. A., Dicke, M. \& Ekesi, S. (2018). Effects of Waste Stream Combinations from Brewing Industry on Performance of Black Soldier Fly, Hermetia illucens (Diptera: Stratiomyidae). PeerJ 6:e5885.

Cullere, M., Tasoniero, G., Giaccone, V., Miotti-Scapin, R., Claeys, E., De Smet, E. \& Dalle Zotte, A. (2016). Black Soldier Fly As Dietary Protein Source For Broiler Quails: Apparent Digestibility, Excreta Microbial Load, Feed Choice, Performance, Carcas and Meat Traits. Animal, 10(2), 1923-1930. Diener, S., Zurbrügg, C. \& Tockner, K. (2009). Conversion of Organic Material by Black Soldier Fly Larvae: Establishing Optimal Feeding Rates. London: SAGE. Dobermann, D., Swift, J.A. \& Field, L.M. (2017). Opportunities and hurdles of edible insects for food and feed. Nutrition Bulletin, 42(4), 293-308. 


\section{JURNAL BIODJATI}

http://journal.uinsgd.ac.id/index.php/biodjati

Dortmans, B.M.A., Diener, S., Verstappen, B.M. \& Zurbrugg, C. (2017). Black Soldier Fly Biowaste Processing - A Step by Step Guide. Eawag : Swiss Federal Institut of Aquatic Science and Technology, Dubendorfm Switzerland.

Elwert, C., Knips, I. \& Katz, P. (2010). A Novel Protein Source: Maggot meal of the Black Soldier Fly (Hermetia illucens) in Broiler Feed. In: Gierus M. Kluth H, Bulang M, Kluge H, editors. Tagung Schweine-und Geflügelernährung. Germany: Universität Halle-Wittenberg.

Gasco, L., Henry, M., Piccolo, G., Marono, S., Gai, F., Renna, M., Lussiana, C., Antonopoulou, E., Mola, P. \& Chatzifotis, S. (2016). Tenebrio molitor Meal in Diets for European Sea Bass (Dicentrarchus labrax L.) Juveniles: Growth Performance, Whole Body Composition And In Vivo Apparent Digestibility. Animal Feed Science and Technology, 220, 34-45.

Gobbi, P., Sánchez, A.M. \& Santos, R. (2013). The Effects of Larval Diet on Adult Life- History Traits of the Black Soldier Fly, Hermetia illucens (Diptera: Stratiomyidae). European Journal Entomology, 110(3), 461-468.

Grant, K. R., Brennan, M. \& Hoad, S. P. (2021). The Structure of the Barley Husk Influences its Resistance to Mechanical Stress. Frontiers in Plant Science, 11, 614334.

Gujral, H. S., Sharma, B. \& Khatri, M. (2018). Influence of Replacing Wheat Bran With Barley Bran on Dough Rheology, Digestibility and Retrogradation Behavior of Chapatti, Food Chemistry 240: 1154-1160.

Hasan, H. A. \& Dina, F. (2019). Cpoccurance od Different Insect Species in Oviposition Media of Black Soldier
Fly, Hermentia illucens (Diptera: Stratiomydae. Serangga, 24(2), 1-4.

Henry, M., Gasco, L., Piccolo, G. \& Fountoulaki, E. (2015). Review on The Use of Insects in the Diet of Farmed fish: Past And Future. Animal Feed Science and Technology, 203, 1-22.

Ji, Y. J., Liu, H. N., Kong, X. F., Blachier, F., Geng, M. M., Liu, Y. Y. \& Yin, Y. L. (2016). Use of Insect Powder As a Source Of Dietary Protein In EarlyWeaned Piglets. Journal of Animal Science, 94(3), 111-116.

Kelemu, S., Niassy, S., Torto, B., Fiaboe, K., Affognon, H., Tonnang, H., Maniania, N. K. \& Ekesi, S. (2015). African Edible Insects for Food and Feed: Inventory, Diversity, Commonalities and Contribution to Food Security. Journal of Insects as Food and Feed, 1(2), 103-119.

Kim, W., Bae, S., Park, K., Lee, S., Choi, Y., Han, S. \& Koh, Y. (2011). Biochemical Characterization of Digestive Enzymes in the Black Soldier Fly, Hermetia illucens (Diptera:Stratiomyidae). Journal of Asia-Pacific Entomology, 14, 11-14.

Lima, U. A (2010. Materias-primas Dos Alimentos. Sao Paulo: Ed Blucher.

Liu,Z., Minor, M., Morel, P.C.H.\& Rodriguez, A. J. N. (2018). Bioconversion of Three Organic Wastes by Black Soldier Fly (Diptera: Stratiomydae) Larvae. Environmental Entomology, 47(6), 1609-1617.

Lock, E. R, Arsiwalla, T. \& Waagbø, R. (2015). Insect Larvae Meal As An Alternative Source Of Nutrients in The Diet of Atlantic Salmon (Salmo salar) Postsmolt. Aquaculture Nutrition, 22(6), 1202-1213.

Lynch, K. M, Steffen, E. J. \& Arendt, E.K. 


\section{JURNAL BIDDJATI}

http://journal.uinsgd.ac.id/index.php/biodjati

(2016). Brewers'Spent Grain: a Review

With an Emphasis on Food And Health.

Review Article. Journal of the institute of brewing, 122(4), 553-568.

Makkar, H. P. S., Tran, G., Heuze, V. \& Ankers, P. (2014). State of the Art on Use of Insects as Animal Feed. Animal Feed Science Technology, 197, 1-33 DOI

Manurung, R., Supriatna, A., Esyanti, R.E. \& Putra, R.E. (2016). Bioconversion of Rice Straw by Black Soldier Fly Larvae (Hermetia illucnes): Optimal Feed Rate for Biomass Production. Journal of Entomology and Zoology Studies, 4(4), 1036-1041

Mathias, Thiago R.D.S., de Mello, Pedro P.M., Servulo. \& Eliana F.C. (2014). Solid Waste in Brewing Process : A Review. Academic Journals, 5(1), 1-9.

Meneguz, M., Schiavone, A., Gai, F., Dama, A., Lussiana, C., Renna, M. \& Gasco, L. (2018). Effect of Rearing Substrate On Growth Performance, Waste Reduction Efficiency and Chemical Composition of Black Soldier Fly (Hermetia Illucens) Larvae. Journal of Science Food Agriculture, 98, 5776-5784.

Moula, N., Scippo, M., Douny, C., Degand, G., Dawans, E., Cabaraux, J., Hornick, J., Medigo, R., Leroy, P., Francis, F. \& Detilleux, J. (2018). Performances of Local Poultry Breed Fed Black Soldier Fly Larvae Reared on Horse Manure. Animal Nutrition, 4, 73-78.

Mussato, S. I., Dragone, G. \& Rroberto, I.C. (2006). Brewers' Spent Grain: Generation, Characteristics And Potential Applications. Journal of Cereal Science, 43, 1-14.

Myers, H. M., Tomberlin, J. K., Lambert, B. D. \& Kattes, D. (2008). Development of Black Soldier Fly (Diptera: Stratiomyidae) Larvae Fed Dairy
Manure. Environmental Entomology, 37, 11-15.

Nguyen, T. T. X., Tomberlin, J. K. \& Vanlaerhoven, S. (2013). Influence of Resources on Hermetia Illucens (Diptera: Stratiomyidae) Larval Development. Journal of Medical Entomology, 50(4), 898-906.

Nguyen, T. T. X., Tomberlin, J. K. \& Vanlaerhoven, S. (2015). Ability of Black Soldier Fly (Diptera: Stratiomyidae) Larvae to Recyle Food Waste. Environmental Entomology, 44, 406-410.

Ohkuma, M. (2003). Termite Symbiotic Systems: Efficient Bio-Recycling of Lignocellulose. Applied microbiology and biotechnology, 61(1), 1-9.

Renna, M., Schiavone, A., Gai, F., Dabbou, S., Lussiana, C., Malfatto, V., Prearo, M., Capucchio, M.T., Biasato, I., Biasibetti, E., De Marco, M., Brugiapaglia, A., Zoccarato, I. \& Gasco, L. (2017). Evaluation of The Suitability of a Partially Defatted Black Soldier Fly (Hermetia Illucens L.) Larvae Meal as Ingredient For Rainbow Trout (Oncorhynchus Mykiss Walbaum) Diets. Journal of Animal Science and Biotechnology, 8(1), 57.

Robertson, J. A., Ianson, K. J. A., Treimo, J., Faulds, C. B., Brocklehhurst, T.F., Eijsink, V.G.H. \& Waldron, K.W. (2010). Profiling Brewers' Spent Grain for Composition and Microbial Ecology at The Site of Production. Food Science and Technology, 43, 890-896.

Schiavone, A., De Marco, M., Martínez, S., Dabbou, S., Renna, M., Madrid, J., Hernandez, F., Rotolo, L., Costa, P., Gai, F. \& Gasco, L. (2017). Nutritional Value of a Partially Defatted and Highly Defatted Black Soldier Fly Larvae (Hermetia illucens L.) Meal for 


\section{JURNAL BIDDJATI}

http://journal.uinsgd.ac.id/index.php/biodjati

\begin{abstract}
Broiler Chickens: Apparent Nutrient Digestibility, Apparent Metabolizable Energy and Apparent Ileal Amino Acid Digestibility. Journal of Animal Science and Biotechnology, 8(1), 51.
\end{abstract}

Scriber, J. M., \& F. Slansky Jr., F. (1981). The Nutritional of Immature Insects. Annual Review of Entomology, 26, 183-211.

Simpson, S. J., \& Simpson C. L. (1990). The Mechanisms of Nutritional Compensation By Phytophagous Insects, 111-160. In E. A. Bernays (ed.), Insect-plant interactions, vol. 2. CRC Press, Boca Raton, FL.

Spranghers, T., Ottoboni, M., Klootwijk, C., Ovyn, A., Deboosere, S., De Meulenaer, B., Michiels, J., Eeckhout, M., De Clercq, P. \& De Smet, S. (2017). Nutritional Composition Of Black Soldier Fly (Hermetia illucens) Prepupae Reared on Different Organic Waste Substrates. Journal of the Science of Food and Agriculture, 97(8), 2594-2600.

Supriyatna A., \& Putra R.E. (2017). Estimasi pertumbuhan larva lalat balck soldier (Hermatia illucens) dan penggunaan pakan jerami padi yang difermentasi dengan jamur P. chrysosporium. Jurnal Biodjati, 2(2), 159-166.
Tomberlin, J .K. \& Sheppard, D.C. (2002). Factors Influencing Mating and Oviposition of Black Soldier Flies (Diptera: Stratiomyidae) in a Colony. Journal of Entomological Science, 37(4), 345-352.

Van Huis, A., Van Itterbeeck, J., Klunder, H., Mertens, E., Halloran, A., Muir, G. \& Vantomme, P. (2013). Edible Insects: Future Prospects for Food and Feed Security. Rome: Food and Agriculture Organization of the United Nations, FAO Forestry, Paper 171.

Veldkamp, T. \& Bosch, G. (2015). Insects: a protein-rich feed ingredient in pig and poultry diets. Animal Frontiers, 5, 4550.

Zheng, L.Y., Hou, Y.F., Li, W., Yang, S., Li, Q. \& Yu, Z. N. (2012). Biodiesel Production From Rice Straw and Restaurant Waste Employing Black Soldier Fly Assisted by Microbes. Energy, 47, 225-229

Wang, S., Dai, G., Haiping, Y. \& Luo, Z. (2017). Lignocellulosic biomass pyrolysis mechanism: A State of the Art Review. Progress in Energy Combustion Science, 62, 33-86. 